\title{
Use of infant donor tissue in endothelial keratoplasty
}

Majid Moshirfar'

Yichieh Shiuey ${ }^{2}$

Carlton Robert Fenzl ${ }^{3}$

'Department of Ophthalmology, Francis I Proctor Foundation, University of California San Francisco, San Francisco, CA, USA; ${ }^{2}$ Palo Alto Medical Foundation, Sunnyvale, CA, USA; 3John A Moran Eye Center, University of Utah, Salt Lake City, UT, USA
Correspondence: Majid Moshirfar Department of Ophthalmology, Francis I Proctor Foundation, University of California San Francisco, 10 Koret Way, KIOI, San Francisco, CA

94143-0730, USA

$\mathrm{Tel}+\mid$ II 5502332 I

Fax +I 4I54760336

Email majid.moshirfar@ucsf.edu
This article was published in the following Dove Press journal:

Clinical Ophthalmology

14 January 2015

Number of times this article has been viewed

\section{Dear editor}

We have read with great interest the recent article by Kobayashi et al describing endothelial keratoplasty using infant donor tissue. ${ }^{1}$ This is a fine case report describing the use of infant donor tissue as a viable source when performing non-Descemet stripping automated endothelial keratoplasty (nDSAEK). Descemet stripping automated endothelial keratoplasty (DSAEK) and nDSAEK seem to be the only currently accepted forms of keratoplasty for which donor tissue under the age of 2 years is acceptable. When used to perform penetrating keratoplasty, it is known that infantile grafts behave in an ectatic fashion., ${ }^{2,3}$ This is likely due to their more elastic properties. Tissue preparation in Descemet membrane endothelial keratoplasty (DMEK) proves to be too difficult given the strength of adhesion of Descemet membrane to the overlying stroma. ${ }^{1}$

We would also like to bring to your attention the article entitled "Use of infant donor tissue for endokeratoplasty", published in the Journal of Cataract and Refractive Surgery in December of 2001. ${ }^{2}$ Shiuey and Moshirfar ${ }^{4}$ describe the use of infant tissue (20 months) in the successful performance of this procedure. While this variation of endokeratoplasty is seldom performed in 2014, substitution of diseased host endothelium with that of an infant was performed. Endothelial cell counts similar to those described in the current article were documented.

Given that the article by Shiuey and Moshirfar was the first to describe replacement of posterior tissue with that of an infant while leaving the anterior corneal stroma and epithelium intact, we thought it would be a valuable reference to be mentioned for readers interested in this topic. Once again, we would like to congratulate and commend the authors of the current article on the success of the procedure and the value that it provides for future generations of corneal surgeons performing DSAEK and nDSAEK.

\section{Disclosure}

The authors report no conflicts of interest in this work.

\section{References}

1. Kobayashi A, Yokogawa H, Yamazaki N, Masaki T, Sugiyama K. Endothelial keratoplasty with infant donor tissue. Clin Ophthalmol. 2014;8:1827-1830.

2. Gloor P, Keech RV, Krachmer JH. Factors associated with high postoperative myopia after penetrating keratoplasties in infants. Ophthalmology. 1992;99(5):775-779.

3. Koenig S, Graul E, Kaufman HE. Ocular refraction after penetrating keratoplasty with infant donor corneas. Am J Ophthalmol. 1982;94(4):534-539.

4. Shiuey Y, Moshirfar M. Use of infant donor tissue for endokeratoplasty. J Cataract Refract Surg. 2001; 27(12):1915-1918. 


\section{Publish your work in this journal}

Clinical Ophthalmology is an international, peer-reviewed journal covering all subspecialties within ophthalmology. Key topics include: Optometry; Visual science; Pharmacology and drug therapy in eye diseases; Basic Sciences; Primary and Secondary eye care; Patient Safety and Quality of Care Improvements. This journal is indexed on

Submit your manuscript here: http://www.dovepress.com/clinical-ophthalmology-journal
PubMed Central and CAS, and is the official journal of The Society of Clinical Ophthalmology (SCO). The manuscript management system is completely online and includes a very quick and fair peer-review system, which is all easy to use. Visit http://www.dovepress.com/ testimonials.php to read real quotes from published authors. 